\title{
PEMANFAATAN APLIKASI AZ SCREEN RECORDER UNTUK MENDUKUNG PEMBELAJARAN DARING
}

\author{
Aria Bayu Setiaji ${ }^{1 *}$, Enggal Mursalin ${ }^{2}$ \\ ${ }^{1}$ Prodi Tadris Bahasa Indonesia, IAIN Ambon, Indonesia \\ ${ }^{2}$ Prodi Tadris IPA, IAIN Ambon, Indonesia \\ ariabayu@iainambon.ac.id
}

\begin{abstract}
ABSTRAK
Abstrak: Media pembelajaran berperan penting dalam menunjang proses pembelajaran. Terlebih, adanya pandemi Covid-19 yang menyebabkan bentuk pembelajaran berubah menjadi pembelajaran jarak jauh (daring). Untuk itu, guru perlu memiliki keterampilan dalam membuat media pembelajaran untuk menunjang hal tersebut. Pelaksanaan kegiatan Pengabdian kepada Masyarakat $(\mathrm{PkM})$ ini bertujuan untuk meningkatkan keterampilan guru dalam membuat media pembelajarn dengan menggunakan aplikasi $A Z$ screen recorder. Melalui kegiatan $\mathrm{PkM}$ dalam bentuk pelatihan ini guru-guru diharapkan, 1) memiliki motivasi dalam menggunakan media pembelajran; dan 2) memiliki keterampilan dalam membuat media pembelajaran. Peserta pelatihan yakni sebanyak 22 orang guru-guru Yayasan Al-Ansor Kota Ambon yang terdiri dari guru MI. MTs, dan MA. Kegiatan pelatihan ini dilaksanakan melalui metode ceramah, diskusi interaktif dan demonstrasi. Pelatihan ini menunjukan hasil yakni, 1) meningkatnya motivasi gugu-guru dalam menggunakan media pembelajaran, 2) guru-guru memiliki keterampilan dalam membuat media pembelajaran (video) menggunakan aplikasi $A Z$ screen recorder. Kegitan pelatihan yang dilakukan berjalan dengan lancar dan sesuai dengan tujuan yang diharapkan. Dari 22 peserta, tercatat 20 peserta telah berhasil membuat video pembelajaran menggunakan aplikasi $A Z$ screen recorder.
\end{abstract}

Kata Kunci: pelatihan guru; video pembelajaran; $A Z$ screen recorder; pembelajaran daring; pandemi covid-19

Abstract: Learning media plays an important role in supporting the learning process. Moreover, the Covid-19 pandemic has caused the form of learning to change to online learning. For this reason, teachers need to have skills in making learning media to support this. The implementation of this Community Service (PkM) activity aims to improve teacher skills in making learning media using the $A Z$ screen recorder application. Through PkM activities in the form of this training, teachers are expected to 1) have motivation in using learning media; and 2) have skills in making learning media. The training participants were 22 teachers from the Yayasan Al-Ansor in Ambon City, consisting of MI, MTs, and MA teachers. This training activity is carried out through lecture methods, interactive discussions, and demonstrations. This training shows the results, namely, 1) increased motivation of teachers in using learning media, 2) teachers have skills in making learning media (video) using the $A Z$ screen recorder application. The training activities carried out ran smoothly and in accordance with the expected goals. Of the 22 participants, 20 participants have succeeded in making learning videos using the $A Z$ screen recorder application.

Keywords: teacher training, learning videos, AZ Screen Recorder, covid-19 pandemic

\section{A. LATAR BELAKANG}

Adanya pandemi Covid-19 menyebabkan pola pendidikan di Indonesia berubah. Awalnya pembelajaran yang dilakukan dengan tatap muka, berubah menjadi 
pembelajaran daring atau jarak jauh (Dewi, 2020; Winangun \& Dewi, 2021; Kholisho et al., 2021; Astuti, Dasmo, \& Bhakti, 2021; Susanti, Aflaha, \& Taufik, 2021). Dengan diterapkanya pembelajaran daring atau jarak jauh menuntut guru untuk terampil dalam mendesain pembelajaran yang inovatif sehingga mutu dan tujuan pembelajaran tetap dapat tercapai (Asmuni, 2020; Winarsieh \& Rizqiyah, 2020; Winangun \& Dewi, 2021; Wahyuni, Rahmadhani, \& Mandasari, 2020). Salah satu bentuk inovasi pembelajaran yang dapat dilakukan guru dalam melaksanakan pembelajaran jarak jauh dengan mendesain media pembelajaran yang bersifat e-learning atau memanfaatkan teknologi (Mursalin, 2010; Suwardiyanto \& Yuliandoko, 2017; Resmini, Satriani, \& Rafi, 2021). Misalnya guru dapat memanfaatkan berbagai aplikasi untuk merancang media pembelajaran daring.

Media pembelajaran menjadi sangat penting dalam mendukung tercapainya tujuan pembelajaran. Fungsi media dalam pembelajaran sebagai penyalur pesan (Soemantri, 2019), memperjelas pesan pembelajaran (Susilana \& Riyana, 2009), meningkatkan efisiensi penyampaian pesan pembelajaran (Marlena, Dwijayanti, \& Edwar, 2018) dan meningkatkan motivasi belajar siswa (Dai \& Fan, 2012; Arigiyati, Kuncoro, \& Kusumaningrum, 2021; Supriyono, 2019). Pengemasan media pembelajaran yang baik juga dapat berpengaruh terhadap tercapainya tujuan pembelajaran (Hanum, 2013). Contoh media yang dapat digunakan dalam pembelajaran seperti slide, film, video dan filmstrip (Sunardi, Sahputra, \& Hidayah, 2021).

Peran teknologi dalam pendidikan memiliki pengaruh besar dalam membantu menciptakan media-media pembelajaran yang inovatif. Apalagi saat ini banyak aplikasiaplikasi yang mudah kita temukan untuk mendukung pembuatan media pembelajaran (Arigiyati, Kusumaningrum, \& Kuncoro, 2021). Namun ketersediaan fasilitas dan teknologi yang ada belum dapat dioptimalkan dengan baik. Kendala sering ditemukan yaitu kurangnya keterampilan dan pengetahuan tentang aplikasi dan internet (Widarma, Irawan, \& Simargolang, 2019). Kendala tersebut juga penulis temukan sebagian besar guru di Yayasan Al-Ansor Kota Ambon. Bedasarkan hasil observasi awal penulis menemukan kendala antara lain 1) minimnya kesadaran guru dalam menerapkan media pembelajaran, 2) kurangnya pengetahuan guru dalam membuat video pembelajaran, 3) guru memiliki fasilitas pendukung seperti smartphone dan internet tapi belum dapat memanfaatkan untuk membuat media pembelajaran. Padahal salah satu kompetensi penting yang harus dikembangkan oleh guru dalam melaksanakan proses pembelajaran sebagai bentuk profesionalitasnya yakni membuat alat peraga/media pembelajaran yang menarik (Mursalin \& Setiaji, 2021).

Berdasarkan kendala-kendala yang ditemukan, maka penulis menganggap penting untuk mengadakan pelatihan bagi guru-guru dalam pembuatan media pembelajaran dengan memanfaatkan aplikasi $A Z$ screen recorder. Salah satu media yang dibuat guru yaitu media audio visual atau dalam bentuk video pembelajaran. Hal tersebut dipilih karena video pembelajaran merupakan media yang dapat menampilkan informasi secara lengkap seperti teks, suara, animasi (Marjuni \& Harun, 2019; Rusmiyati, 2014). Selain itu, video pembelajaran lebih bersifat fleksibel karena dapat diakses dimanapun, kapanpun tanpa batas ruang dan waktu (Dai \& Fan, 2012).

Berdasarkan uraian permasalahan di atas, maka dinilai penting untuk melakukan pelatihan pembuatan media pembelajaran dengan mengunakan aplikasi $A Z$ screen recorder. Pelatihan ini merupakan kegiatan pengabdian kepada masyarakat dengan tujuan meningkatkan kompetensi guru-guru yayasan Al-Ansor Ambon dalam merancang media pembelajaran daring.

\section{B. METODE PELAKSANAAN}

Kegiatan Pengabdian kepada Masyarakat (PkM) dalam bentuk pelatihan ini dilaksanakan pada hari Sabtu, 6 Maret 2021. Metode yang digunakan pada pelatihan ini 
72 | PEKAMAS (Pengabdian Kepada Masyarakat) | Vol. 1, No. 2, Desember 2021, hal. 70-78

yakni ceramah, diskusi interaktif, demonstrasi dan praktik. Alat dan bahan yang diperlukan yakni Smartphone, LCD Proyektor, dan slide materi pembelajaran. Adapun yang menjadi sasaran utama kegiatan pelatihan ini adalah guru-guru Yayasan Al-Ansor Ambon yang berjumlah 22 orang.

Secara rinci, jumlah peserta diuraikan pada tabel berikut:

Tabel 1. Jumlah Peserta Pelatihan

\begin{tabular}{cll}
\hline No & Guru/Jenjang Pendidikan & Jumlah \\
\hline 1 & MI & 3 Orang \\
\hline 2 & MTs & 7 Orang \\
\hline 3 & MA & 12 Orang \\
\hline Jumlah Keseluruhan & 22 Orang \\
\hline
\end{tabular}

Selanjutnya tahapan kegiatan dalam pelatihan ini diuraikan melalui tabel berikut:

Tabel 2. Rincian Pelaksanaan Kegiatan Pengabdian kepada Masyarakat (PkM)

\begin{tabular}{ccccc}
\hline Alokasi & Materi & Waktu & Metode & Pemateri \\
\hline Sesi I & $\begin{array}{c}\text { Pemanfaatan Aplikasi } \\
\text { AZ screen recorder } \\
\text { dalam membuat } \\
\text { video pembelajaran }\end{array}$ & $\begin{array}{c}8.30-12.00 \\
\text { WIT }\end{array}$ & $\begin{array}{c}\text { Ceramah dan } \\
\text { Diskusi } \\
\text { Interaktif }\end{array}$ & $\begin{array}{c}\text { Aria Bayu Setiaji, M.Pd } \\
\text { Enggal Mursalin M.Pd }\end{array}$ \\
\hline Sesi II & $\begin{array}{c}\text { Pembuatan video } \\
\text { pembelajaran } \\
\text { mengunakan aplikasi } \\
\text { AZ screen recorder }\end{array}$ & $\begin{array}{c}13.00-16.00 \\
\text { WIT }\end{array}$ & $\begin{array}{c}\text { Demonstrasi } \\
\text { dan Praktik }\end{array}$ & $\begin{array}{c}\text { Aria Bayu Setiaji, M.Pd } \\
\text { Enggal Mursalin M.Pd }\end{array}$ \\
& & & \\
\hline
\end{tabular}

\section{HASIL DAN PEMBAHASAN}

Rangkaian kegiatan ini dilaksanakan guna menjawab permasalahan yang ada. Secara garis besar permasalahan yang ditemukan yaitu minimnya kesadaran guru dalam menggunakan media pembelajaran dan kurangnya pemahaman guru dalam membuat media pembelajaran. Untuk lebih jelasnya gambaran permasalahan, solusi, dan output kegiatan ini dapat dilihat pada gambar 1 berikut.

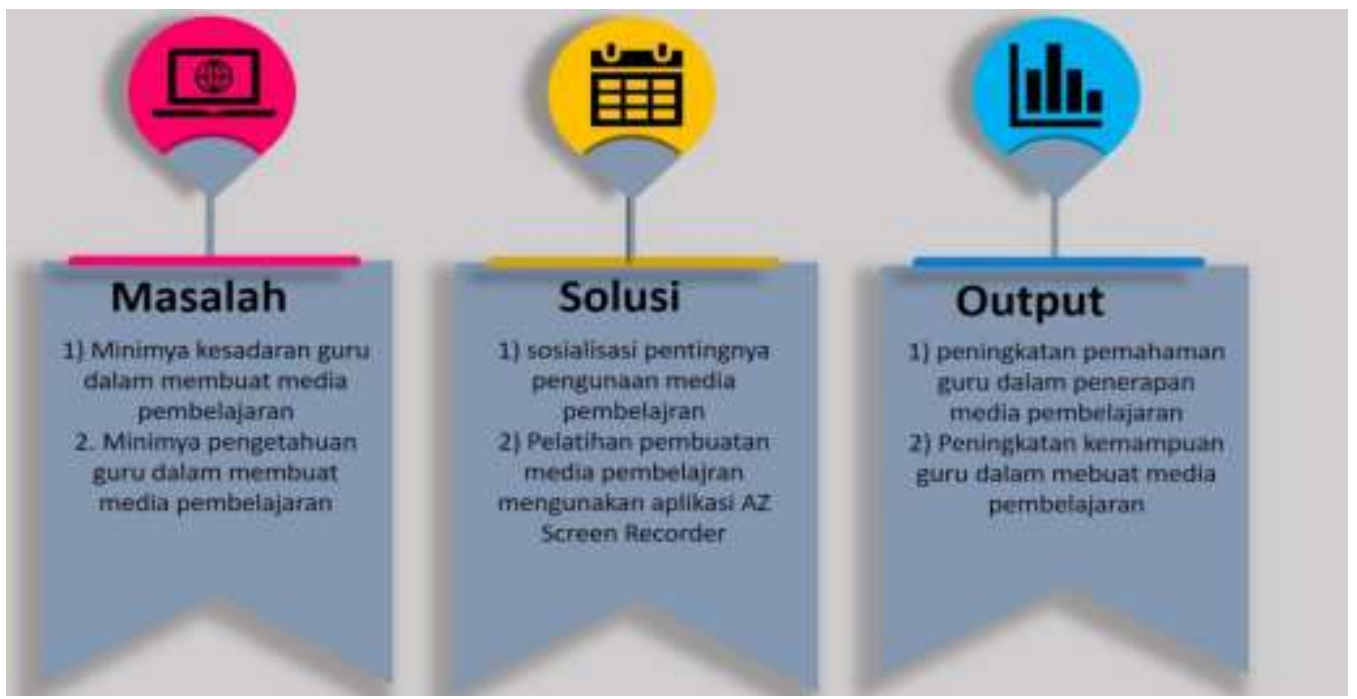

Gambar 1. Permasalahan, solusi dan output kegiatan pengabdian

Berdasarkan hasil kegiatan setiap sesi pelaksanaan pelatihan, diketahui antusias dan 
motivasi guru meningkat dalam hal menerapkan dan merancang media pembelajaran. Hal tersebut dilihat dari umpan balik guru-guru ketika mengikuti pelatihan. Sebagian besar guru-guru aktif dalam mengikuti pelatihan dan aktif bertanya terkait hal-hal dalam pembuatan video pembelajaran mengunakan aplikasi $A Z$ screen recorder. Bahkan beberapa guru menyarankan agar pada kesempatan lain dapat memberikan pelatihan pembuatan media pembelajaran dengan menggunakan aplikasi lainya. Lebih lanjut hasil dari kegiatan dapat digambarkan seperti pada grafik di bawah ini.

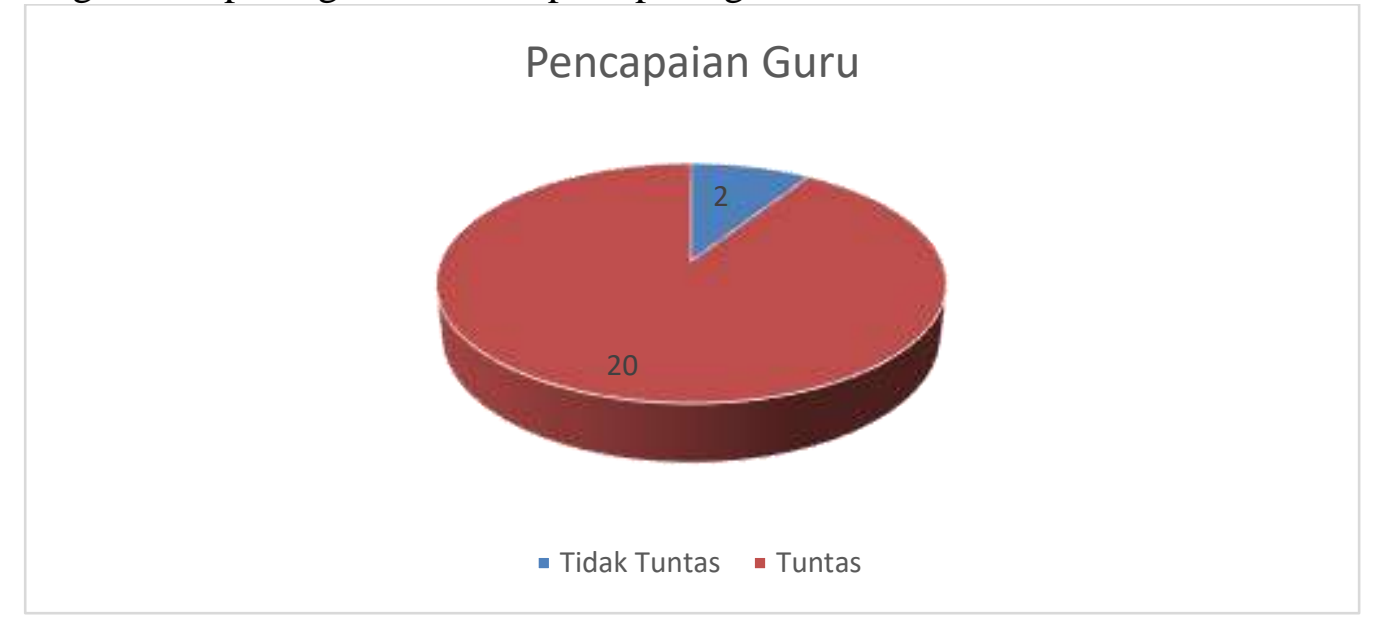

\section{Gambar 2. Hasil Pencapaian Pengabdian kepada Masyarakat (PkM)}

Pelaksanaan kegiatan pelatihan pembuatan media pembelajaran menggunakan aplikasi AZ screen recorder bagi guru-guru Yayasan Al Ansor Ambon dapat berjalan sesuai dengan tujuan yang diharapkan. Dari 22 peserta yang mengikuti pelatihan, 20 peserta pelatihan sudah berhasil membuat video pembelajaran dengan menggunakan aplikasi AZ screen recorder. Berdasarkan hasil kegiatan yang telah dilakukan, diharapkan kedepanya guru-guru dapat mengembangkan dan meningkatkan ketrampilannya dalam membuat video pembelajaran untuk dapat digunakan dalam pembelajaran daring maupun luring.

Pelaksanaan kegiatan PkM ini dilakukan melalui dua sesi, secara detail dapat diuraikan sebagai berikut.

\section{Sesi I}

Pada sesi I ini, peserta diberikan materi terkait aplikasi AZ screen recorder. Aplikasi $A Z$ screen recorder merupakan aplikasi perekam layar yang dapat dioperasikan melalui smartphone android. Hasil rekaman layar dari smartphone android itulah yang akan diekspor menjadi video pembelajaran. Aplikasi ini juga dapat digunakan untuk live streaming.

Pemilihan aplikasi $A Z$ screen recorder sebagai apikasi pembuat video pembelajaran dengan alasan 1) aplikasi ini gratis dan dapat digunakan semua jenis smartphone android, 2) apikasi mudah digunakan dan tidak rumit, 3) proses pembuatan video tidak membutuhkan waktu lama sehingga tidak menyita banyak waktu. Meskipun banyak kelebihan, aplikasi $A Z$ screen recorder juga memiliki kekurangan. Adapun kekurangan aplikasi ini yaitu hanya dapat menampilkan separuh badan ketika merekam.

Kegiatan sesi I ini dilakukan kurang lebih selama 120 menit. Narasumber menyampaikan materi selama 90 menit, kemudian dilanjutkan diskusi atau tanya jawab selama 30 menit. Materi yang disampaikan meliputi 1) Penjelasan mengenai kegunaan aplikasi $A Z$ screen recorder, 2) penjelasan mengenai fitur-fitur yang dapat digunakan pada aplikasi $A Z$ screen recorder, 3) pemaparan contoh pembuatan video pembelajaran melalui aplikasi $A Z$ screen recorder. Materi ini disampaikan kepada peserta pelatihan guna memberikan pemahaman dan keterampilan dalam memanfaatkan aplikasi dalam membuat video pembelajaran yang mudah dan sederhana. Pada sesi ini peserta mengikuti dengan antusias dan termotivasi untuk membuat video pembelajaran. Hal tersebut dilihat 
74 | PEKAMAS (Pengabdian Kepada Masyarakat) | Vol. 1, No. 2, Desember 2021, hal. 70-78

dari umpan balik yang diberikan oleh peserta pelatihan.

Sesi II

Setelah seluruh peserta memahami materi yang disampaikan pada sesi I, selanjutnya pada sesi II ini peserta mempraktikkan cara membuat video pembelajaran menggunakan aplikasi AZ screen recorder. Pada sesi ini narasumber I mendampingi dan memandu peserta pelatihan untuk membuat video pemelajaran. Adapun langkah-langkah kegiatan pembuatan video pembelajaran sebagai berikut.

\section{Tahap Persiapan}

Pada Tahap persiapan, peserta diminta untuk menyiapkan file materi pembelajaran yang akan dijadikan video pembelajaran. File yang disiapkan dalam format powerpoint atau PDF. Selanjutnya peserta menyiapkan smartphone android dan mendowload aplikasi AZ screen recorder di PlayStore. Adapun aplikasi yang didownload tersebut dapat dilihat pada gambar berikut.
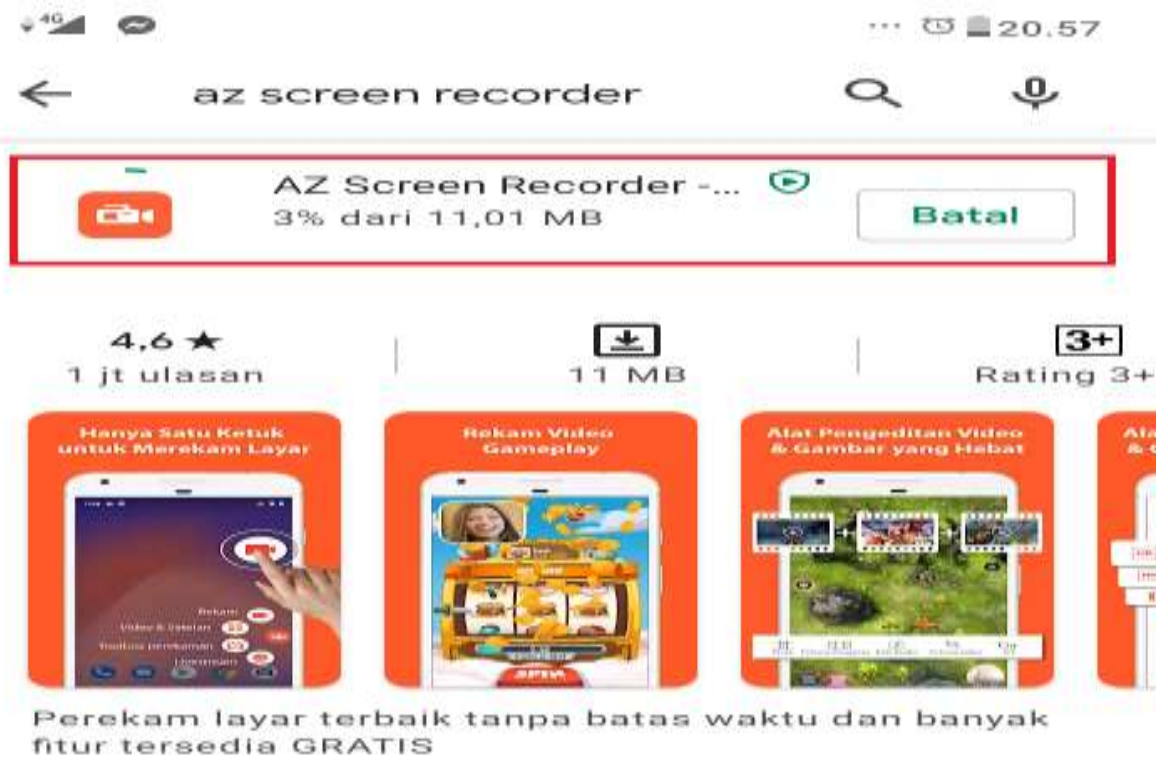

Gambar 3. Download aplikasi $A Z$ screen recorder

\section{Tahap Pelaksanaan}

Tahap pelaksanaan pembuatan video pembelajaran dimulai dengan membuka powerpoint atau file PDF materi yang akan diajarkan. Materi tersebut dibuka menggunakan smartphone android masing-masing. Contoh materi dapat dilihat pada gambar berikut.

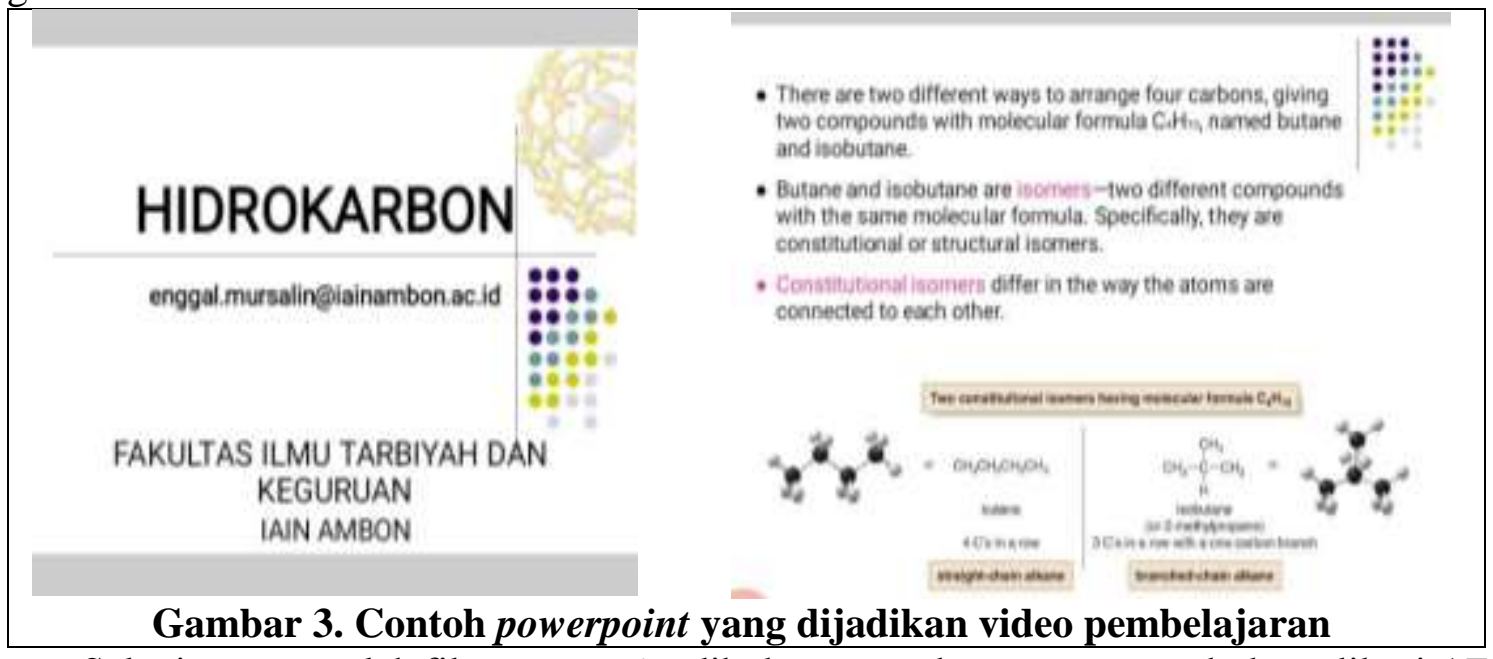

Selanjutnya, setelah file powerpoint dibuka, secara bersamaan membuka aplikasi $A Z$ screen recorder. Untuk lebih jelasnya dapat dilihat pada penjelasan berikut. 


\section{Membuka Aplikasi $A Z$ screen recorder}

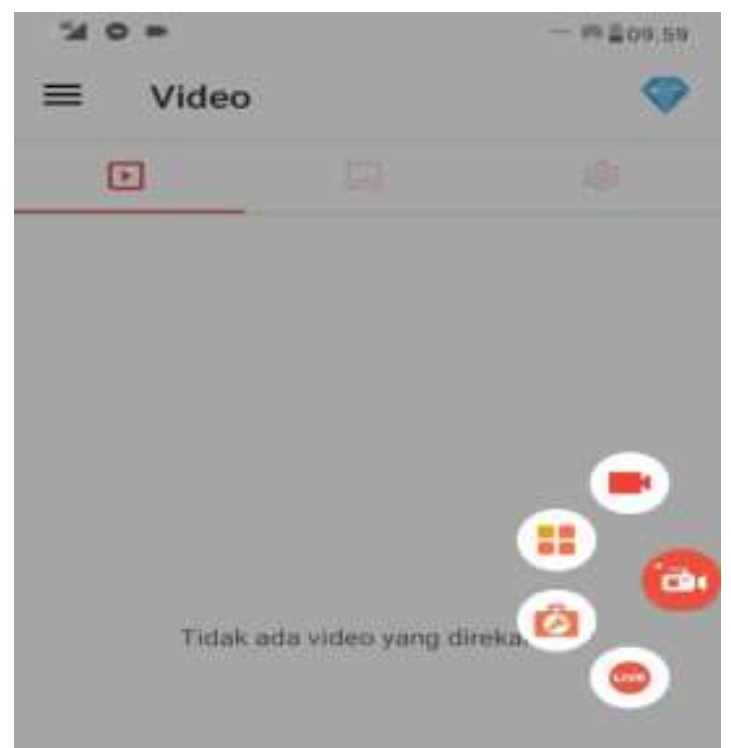

Pada tahap ini peserta membuka aplikasi $A Z$ screen recorder pada Smartphone masing-masing. Untuk dapat merekam video perlu mengizinkan akses aplikasi merekam video seperti pada gambar berikut.

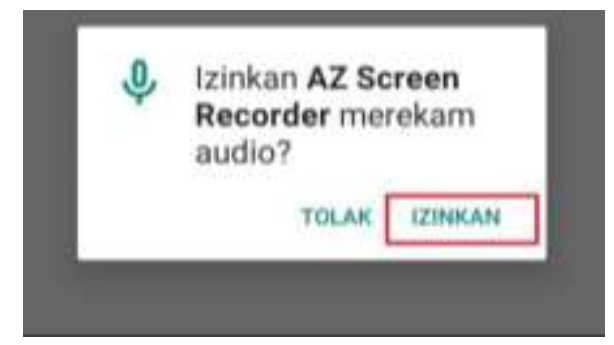

\section{Mengaktifkan Fitur Kamera dan Kuas}
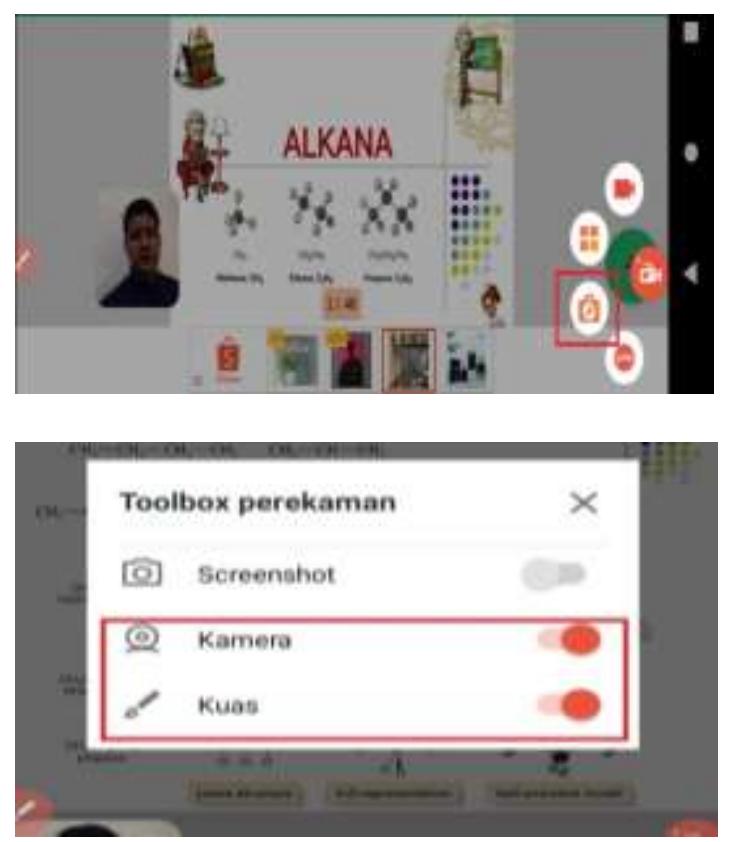

3. Memulai Melakukan Perekaman

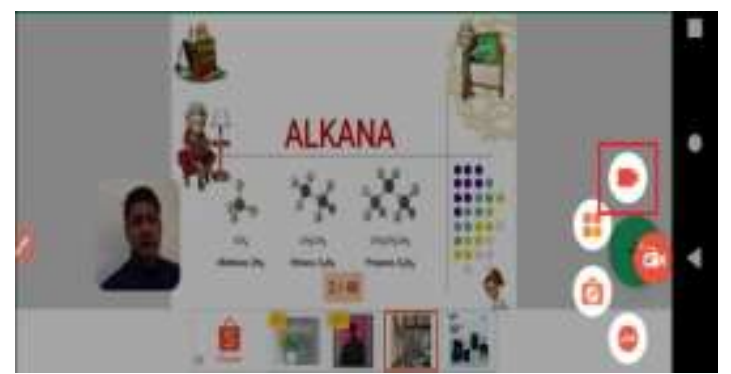

Setelah $A Z$ screen recorder terbuka secara bersamaan membuka juga file materi yang akan diajarkan. Sebelum memulai merekam maka perlu mengatur aplikasi dengan memilih tombol pengaturan. Setelah dipilih tombol pengaturan aktifkan fitur kamera dan kuas. Fitur kamera berfungsi untuk menampilkan pembicara atau pemateri sedangkan fitur kuas berfungsi untuk membuat coteratan pada layar salayaknya ketika kita menjalaskan di papan tulis.

Setelah fitur kamera dan kuas sudah dinyalakan, dan materi yang sudah diajarkan sudah terbuka maka selanjutnya mulai merekam. Cara memulai rekaman dengan menekan tombol icon video seperti pada gambar di samping. Ketika sudah menekan tombol merekam maka guru menjelaskan materi yang tampil di layar smartphone. Untuk mendukung penjelasan materi guru juga dapat mengunakan fitur kuas untuk membuat coretan-coretan pada layar. 
76 | PEKAMAS (Pengabdian Kepada Masyarakat) | Vol. 1, No. 2, Desember 2021, hal. 70-78

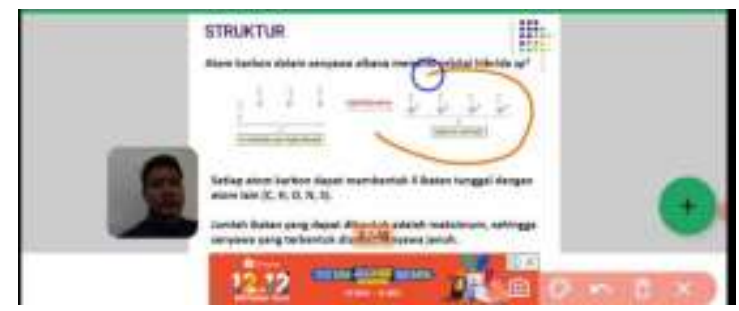

\section{Menyimpan Video ke Galeri}

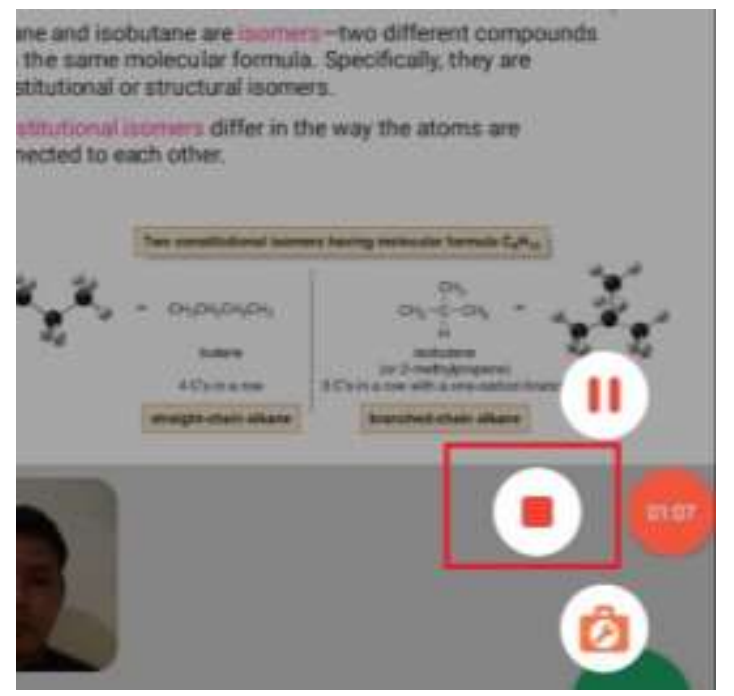

Setelah guru selesai menjelaskan semua materi pembelajaran maka untuk menyimpan video dapat menekan tombol stop. Setelah tombol stop ditekan maka secara otomatis video hasil rekaman secara otomatis akan tersimpan ke galeri smartfom. Seperti gambar berikut.

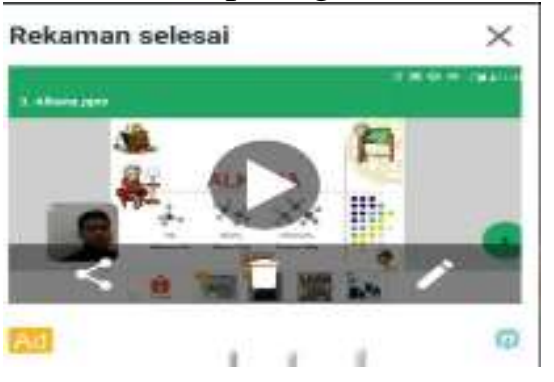

\section{Tahap Penyelesaian Video}

Setelah video rekaman tersimpan di smartphone android maka perlu di cek kembali hasil rekaman tersebut. Misalnya kualitas atau kejelasan suara dan gambar. Kekurangan dalam perekaman video umumnya terjadi pada suara yang tidak jelas. Hal tersebut dikarenakan adanya kebisingan saat merekam. Untuk itu saat merekan harus mencari tempat yang tenang atau jauh dari kebisingan. Setelah video benar-benar bagus dan jelas dari segi suara maupun gambar maka selanjutnya video dapat di bagikan ke siswa-siswa. Video tersebut dapat mendukung pembelajaran daring atau pembelajaran jarak jauh. Siswa dapat belajar di rumah masing-masing dengan melihat video pembelajaran yang telah dibagikan oleh guru. Selain itu guru juga dapat memutar video di kelas dengan bantuan proyektor, apa bila pembelajaran dilakukan dengan tatap muka.

\section{SIMPULAN DAN SARAN}

Pelaksanaan kegiatan Pengabdian kepada Masyarakat (PkM) dalam bentuk pelatihan pembelajaran media pembelajaran dengan menggunakan aplikasi $A Z$ screen recorder ini berjalan dengan lancar dan direspon dengan baik oleh guru sebagai peserta pelatihan. Hal ini dapat dilihat dari antusias peserta dalam mengikuti keseluruhan sesi kegiatan. Selain itu, peserta juga aktif bertanya dan interaksi tentang materi yang disampaikan. Dari 22 peserta yang mengikuti pelatihan, 20 peserta pelatihan sudah berhasil membuat video pembelajaran dengan menggunakan aplikasi $A Z$ screen recorder. Sebagai hasil dari kegiatan ini, guru-guru memperoleh pemahaman dan keterampilan dalam membuat video pembelajaran untuk menunjang pembelajaran daring atau pembelajaran jarak jauh.

\section{DAFTAR RUJUKAN}

Arigiyati, T. A., Kuncoro, K. S., \& Kusumaningrum, B. (2021). Pelatihan Pembuatan Media Pembelajaran Berbasis Smartphone bagi Guru SD Muhammadiyah Girikerto. Kanigara, $1(2), 140-149$. 
Arigiyati, T. A., Kusumaningrum, B., \& Kuncoro, K. S. (2021). Pemanfaatan Videoscribe Dalam Peningkatan Kompetensi Guru. Kanigara, 1(1), 1-9.

Asmuni, A. (2020). Problematika Pembelajaran Daring di Masa Pandemi Covid-19 dan Solusi Pemecahannya. Jurnal Paedagogy, 7(4), 281-288.

Astuti, I. A. D., Dasmo, D., \& Bhakti, Y. B. (2021). Peningkatan Kompetensi Guru dalam Pembuatan Video Animasi Pembelajaran Interaktif dengan Powtoon. Jurnal SOLMA, 10(1), 61-69.

Dai, W., \& Fan, L. (2012). Discussion about the pros and cons and recommendations for multimedia teaching in local vocational schools. Physics Procedia, 33(1), 1144-1148.

Dewi, W. A. F. (2020). Dampak Covid-19 terhadap implementasi pembelajaran daring di Sekolah Dasar. Edukatif: Jurnal Ilmu Pendidikan, 2(1), 55-61.

Hanum, N. S. (2013). E-Learning Effectiveness as Learning Media (Evaluation Study of ELearning Learning Model of Telkom Sandhy Putra Purwokerto Vocational School). Journal of Vocational Research, 3(1), 45-57.

Kholisho, Y. N., Arianti, B. D. D., Jamaluddin, J., Wirasasmita, R. H., Ismatulloh, K., Uska, M. Z., \& Fathoni, A. (2021). Pelatihan pembuatan dan editing video bagi guru SD untuk menghadapi Era Industri 4.0. ABSYARA. Jurnal Pengabdian Pada Masyarakat, 2(1), 119127.

Marjuni, A., \& Harun, H. (2019). Penggunaan Multimedia Online Dalam Pembelajaran. Idaarah: Jurnal Manajemen Pendidikan, 3(2), 194-204.

Marlena, N., Dwijayanti, R., \& Edwar, M. (2018). Pengembangan Media Pembelajaran Multimedia Interaktif Berbasis Flash untuk Meningkatkan Hasil Belajar Mahasiswa. Jurnal Pendidikan Ekonomi Dan Bisnis (JPEB), 6(1), 45-51.

Mursalin, E. (2010). Pengaruh Pembelajaran E-Learning Berbasis Blog Terhadap Hasil Belajar Kimia Materi Pokok Hidrokarbon dan Minyak Bumi. Skripsi: Semarang: FMIPA Unnes.

Mursalin, E., \& Setiaji, A. B. (2021). Capacity Teacher's Strengthening in Writing and Publishing Scientific Research Articles. MANGENTE: JURNAL PENGABDIAN KEPADA MASYARAKAT, 1(1), 1-15.

Resmini, S., Satriani, I., \& Rafi, M. (2021). Pelatihan Penggunaan Aplikasi Canva sebagai Media Pembuatan Bahan Ajar dalam Pembelajaran Bahasa Inggris. Abdimas Siliwangi, 4(2), 335343.

Rusmiyati, I. (2014). Penggunaan Multimedia Dalam Pembelajaran Bahasa Sastra Indonesia Di SMP Negeri 2 Bawen Kabupaten Semarang. Jurnal Teknologi Pendidikan Dan Pembelajaran, 2(2), 56-70.

Soemantri, S. (2019). Pelatihan Membuat Media Pembelajaran Digital. Aksiologiya: Jurnal Pengabdian Kepada Masyarakat, 3(1), 64-69.

Sunardi, D., Sahputra, E., \& Hidayah, A. K. (2021). PELATIHAN PEMBUATAN MEDIA PEMBELAJARAN BERBASIS MULTIMEDIA UNTUK MENINGKATKAN KUALITAS PEMBELAJARAN BAGI GURU SMA MUHAMMADIYAH 4 KOTA BENGKULU. JPMTT (Jurnal Pengabdian Masyarakat Teknologi Terbarukan), 1(1), 2934.

Supriyono, S. (2019). Pentingnya Media Pembelajaran Untuk Meningkatkan Minat Belajar Siswa Sd. Edustream: Jurnal Pendidikan Dasar, 2(1), 43-48.

Susanti, A. I., Aflaha, D. S. I., \& Taufik, I. (2021). Pelatihan Pengembangan Media Pembelajaran pada Guru MI Al Muhammady Mentoro Kecamatan Sumobito. KANGMAS: Karya Ilmiah Pengabdian Masyarakat, 2(1), 32-39.

Susilana, R., \& Riyana, C. (2009). Media Pembelajaran: Hakikat Pengembangan, Pemanfaatan dan Penilaian. In wacana prima. Bandung: Wacana Prima.

Suwardiyanto, D., \& Yuliandoko, H. (2017). Pemanfaatan teknologi sebagai media pembelajaran daring (on line) bagi guru dan siswa di SMK Nu Rogojampi. J-Dinamika: Jurnal Pengabdian Masyarakat, 2(2), 76-88.

Wahyuni, S., Rahmadhani, E., \& Mandasari, L. (2020). Pelatihan Pembuatan Media Pembelajaran Interaktif dengan Menggunakan Powerpoint. Jurnal Abdidas, 1(6), 597-602.

Widarma, A., Irawan, M. D., \& Simargolang, M. Y. (2019). Go Public Dan Go Online Publikasi Kegiatan Desa Menggunakan Wordpress (Studi Kasus: Kelurahan Sei Renggas). Jurnal Anadara Pengabdian Kepada Masyarakat, 1(1), 25-33.

Winangun, I. M. A., \& Dewi, N. P. C. P. (2021). Pelatihan Desain Pembelajaran Inovatif Dimasa 
78 | PEKAMAS (Pengabdian Kepada Masyarakat) | Vol. 1, No. 2, Desember 2021, hal. 70-78

Pandemi Covid-19. Caraka: Jurnal Pengabdian Kepada Masyarakat, 1(1), 1-8.

Winarsieh, I., \& Rizqiyah, I. P. (2020). Peranan Guru dalam Pembelajaran Daring pada Masa

Pandemi Covid-19. Indonesian Journal of Teacher Education, 1(4), 159-164. 